VOX PATRUM 21 (2001) t. 40-41

Monika WÓJCIK

(Lublin, KUL)

\title{
INSTYTUCJE DOBROCZYNNE W LISTACH GRZEGORZA WIELKIEGO
}

Quia regiminis locum, licet immeriti, suscepimus,
ita oportet ut fratrum nostrorum necessitatibus
in quantum facultas suppetit concurramus

Grzegorz Wielki, Ep.I 47

Od samego właściwie początku chrześcijaństwa szeroko propagowana była akcja pomocy chorym i ubogim. Wielokrotnie zachęcali do niej biskupi, sami dając przykład i wspomagając biednych ze środków kościelnych. Obowiązek udzielania pomocy ubogim znalazł swój oddźwięk w pismach m.in. św. Leona Wielkiego, św. Ambrożego, św. Jana Chryzostoma czy św. Augustyna ${ }^{1}$, zaś historyk Sokrates zaświadcza o hojności biskupa Konstantynopola Attyka wobec biednych ${ }^{2}$. W działalność dobroczynną angażowali się także papieże: Symmach (498-514) budował domy dla biednych ${ }^{3}$, zaś Pelagiusz II (579-590) założył w swoim domu przytułek dla osób w podeszłym wieku ${ }^{4}$.

1 Podkreślali oni, że dary złożone ubogim stanowią przysługę wyświadczaną sobie samemu; każdego stać na to, aby coś ze swoich dóbr oddać; bogactwo nie jest złe samo w sobie, ważne jest, jaki się z niego zrobi użytek, a nic nie jest bardziej właściwe wierze i miłości chrześcijańskiej, jak troska o ubogich. Obowiązek wspierania ubogich uważali za łaskę dla wiernych, bo dzięki istnieniu biednych mogli osiągnąć zbawienie. Miłosierdzie względem bliźnich powinno być, ich zdaniem, stałym usposobieniem każdego chrześcijanina, por. T. Kunderewicz, Nauka Ojców Kościoła w przedmiocie rozporzadzeń testamentowych $i$ darowizn na cele dobroczynne, PK 25 (1989) nr 1-2, 309-323.

Warto zauważyć, że nie tylko w pismach Ojców Kościoła odnaleźć można określenia dotyczące ubogich. W jednej z konstytucji cesarskich znajduje się swoista definicja czlowieka biednego: „[...] quis enim pauperior est hominibus, qui et inopia tenti sunt et in xenonem repositi et suis corporibus laborantes necessarium victum sibi non possunt adferre?" (C.1,3,48,3); por. M. Mollat, Les pauvres au Moyen Age, Paris 1955, 11-14; E. Patlagean, Pauvreté économique et pauvreté sociale à Byzance IV-VII siècles, Paris 1977, 101-105; B. Biondi, Il diritto romano cristiano, II, Milano 1962, 174nn.

2 Por. HE VII 25. Miał się on zajmować nie tylko potrzebującymi z jego obszaru, ale wspomagał również inne miasta. Sokrates podaje, że biskup wysłał 300 złotych monet dla Kościoła w Nicei, prosząc oáprzekazanie ich głodnym, i to bez względu na wyznawaną przez nich religię.

${ }^{3}$ Por. Liber Pontificalis 53, 80, 10, ed. L. Duchesne, I, Paris 1955, 263: ,,[...] ad sanctum Laurentium pauperibus habitacula construxit”.

${ }^{4}$ Por. tamże 65, 112, 1, s. 309: „Hic domum suam fecit ptochium pauperum senum”. 


\section{CHRZEŚCIJAŃSKIE ZAKŁADY DOBROCZYNNE PRZED GRZEGORZEM WIELKIM}

Początkowo nie było wystarczającego zaplecza ekonomicznego dla budowy specjalnych instytucji dobroczynnych, toteż działalność charytatywna prowadzona była w domach prywatnych przez wyznaczone osoby. Na uwagę zasługuje zmiana, przyniesiona wraz z religią chrześcijańską, co do pobudek świadczenia pomocy ${ }^{5}$. Zasadnicze znaczenie uzyskała teraz motywacja religijna, obowiązek wspierania ubogich wynikający z wyznawanej wiary ${ }^{6}$. Początki dobroczynnej działalności chrześcijan wiążą się z ustanowieniem diakonów, którzy mieli zajmować się zbieraniem i rozdysponowaniem środków na rzecz ubogich. Do pomocy w tej działalności dołączyły kobiety, nazywane diakonisami. Wszyscy oni podlegali miejscowemu biskupowi, który zachował uprawnienia zwierzchnie w stosunku do całego majątku kościelnego ${ }^{7}$.

5 Por. C.A. Maschi, Humanitas romana e caritas cristiana come motivi giuridici, „Jus” 1 (1950) 267-274.

${ }^{6}$ Pojawiła się, jak to ujmuje J. Imbert (Les hôpitaux en droit canonique, Paris 1947, 12), ,une organisation charitable totalement désinteressée, avec un personnel ayant pour unique tâche de collecter et de répartir les aumônes". Euzebiusz (HE VII 22; IX 8) zaświadcza o ofiarnej postawie chrześcijan w czasie różnego rodzaju klęsk i zarazy; mieli oni - w odróżnieniu od pogan - odwiedzać i pielęgnować chorych, przyjmując ze spokojem możliwość zarażenia; grzebali też zmarlych; w czasie głodu zajmowali się rozdawnictwem chleba. Historyk ten cytuje list Dionizego Korynckiego (HE IV 23), który opisuje hojność rzymskich chrześcijan w odniesieniu do ubogich, również poprzez wysyłanie darów dla innych Kościołów.

${ }^{7}$ Por. Imbert, dz. cyt., s. $11 \mathrm{nn}$; autor skłonny jest uznać powstanie swoistego „, droit charitable”, które regulować miało powoływanie osób odpowiedzialnych za działalność dobroczynną, zasady dotyczące gospodarowania majątkiem, sposoby jego podziału. Były to reguły oparte na zwyczaju i nie do końca dziś poznane. O sposobach świadczenia pomocy - o charakterze niezinstytucjonalizowanym - na terenie Afryki por. J. Śrutwa, Majątek kościelny i jego funkcja społeczna w Afryce tacińskiej w II-V wieku, RTK 28 (1981) z. 4, 14-26. O roli i statusie diakonów i diakonis zob. m.in. K. Bihlmeyer - H. Tüchle, Historia Kościoła, I: Starożytność chrześcijańska, thum. J. Klenowski, Warszawa 1971, 114-115; P.G. Caron, Lo 'status' delle diaconesse nella legislazione giustinianea, w: Atti dell'Accademia Romanistica Costantiniana VIII, Napoli 1990, 509-515; J. Colson, Diakon i biskup w pierwszych trzech stuleciach Kościoła, tłum. M. Marczewski, VoxP 9 (1989) z. 17, 587-595; J. Gaudemet, L'Église dans l'Empire romain (IV-V siècles), Paris 1958, 122 124; A.G. Hamman, Vie liturgique et vie sociale, Paris 1968, 93-128 i 139-147; M. Marczewski, Posługa charytatywna diakona w Kościele pierwszych wieków, VoxP 16 (1996) t. 30-31, 217-228.

Od II w. praktykowano spisywanie tzw. matriculae pauperum, czyli listę osób potrzebujących (sieroty, wdowy, biedni), wspieranych przez Kościól. O znaczeniu tego terminu i późniejszej ewolucji por. M. Rouche, La matricule des pauvres. Evolution d'une institution de charité du Bas Empire jusqu'à la fin du Haut Moyen Age, w: Études sur l'histoire de la pauvreté, red. M. Mollat, I, Paris 1974, 83-110 oraz polemicznie: M. De Waha, La matricule des pauvres, „Byzantion” 46 (1976) 354-367.

Majątek kościelny powstawał głównie dzięki ofiarności wiernych i nadaniom cesarskim. W 321 r. przyznano Kościołowi (C.Th. 16, 2, 4) możność nabywania dóbr przekazanych w akcie ostatniej woli (testamenti factio passiva). Od tego okresu majątek kościelny ulegał systematycznemu po- 
Środki podlegające rozdysponowaniu wśród biednych czy chorych pochodziły w dużej mierze od wiernych ${ }^{8}$. W V wieku papież Gelazy ustalił sposób podziału otrzymywanych przez Kościół dóbr ${ }^{9}$. Miały one być dzielone na cztery części (quattuor portiones): jedna pozostawała biskupowi, druga rozdzielana była duchownym, trzecia przeznaczona była na wsparcie ubogich, ostatnia na utrzymanie budynków kościelnych ${ }^{10}$.

Jednocześnie obserwować można wyraźny proces przekształcania formy świadczonej pomocy, w kierunku tworzenia specjalnych miejsc dla przyjmowania osób, które potrzebowały wsparcia. Zaczęły powstawać pierwsze szpitale, domy dla opuszczonych dzieci, sierot i przytułki dla osób starszych. Przyjmuje się powszechnie, że to właśnie dzięki chrześcijaństwu takie domy rozwinęły działalność. Zdaniem Millera, to chrześcijaństwo stworzyło szpitale w Cesarstwie Bizantyńskim $^{11}$; w podobnym tonie wypowiadają się m.in. Szumowski i Jones ${ }^{12}$.

większaniu. Na ten temat por. I. Milewski, Majątek kościelny i jego funkcja w świetle pism Kapadockich Ojców Kościoła i Jana Chryzostoma, VoxP 18 (1998) z. 34-35, 415-435; G. Putrino, Il patrimonio della Chiesa di Roma in Sicilia durante il pontificato di San Gregorio Magno, Roma 1984; La carità cristiana in Roma, ed. V. Monachino, Bologna 1968, 102-104; Gaudemet, L'Église, dz. cyt., s. 288-315.

${ }^{8}$ Por. Gaudemet, L'Église, dz. cyt., s. 291-299; La carità, dz. cyt., s. 45-48 i 70-74; Srutwa, dz. cyt., s. 11-14; również E. Wipszycka, Les ressources et les activités économiques des églises en Égypte du IV au VIII siècle, Bruxelles 1972, 65-92 (źródła papirusowe dotyczące gromadzenia środków przez kościoły egipskie).

${ }^{9}$ Por. Epistula 9, 27, PL 59, 56.

${ }^{10}$ Por. C. Trezzini, La legislazione canonica di Papa S. Gelasio I (492-496), Locarno 1911, 84nn. Działalność dobroczynna zapewniła Gelazemu miano „przyjaciela ubogich” (Liber Pontificalis I 51). Dwie uwagi wydają się też istotne, jeżeli chodzi o papieską decyzję. Po pierwsze, postanowienie to stanowiło pewne ograniczenie w swobodzie dysponowania środkami kościelnymi przez biskupa, ale nie podważało zasady, że to właśnie on sprawował władzę nad majątkiem (C. Trezzini, dz. cyt., s. 196-198). Po drugie, taka forma podziału dóbr stanowiła jedynie wskazanie praktyczne, nie doprowadziła do stałego rozbicia majątku kościelnego na jakieś odrębne części, zob. P.G. Caron, La proprietà ecclesiastica nel diritto del tardo impero, w: Atti dell'Accademia Romanistica Costantiniana IX, Napoli 1993, 222-223; R. Monier - G. Cardascia - J. Imbert, Histoire des institutions et des faits sociaux, des origines à l'aube du Moyen Âge, Paris 1955, 538.

$" 1$ Por. T.S. Miller, The birth of the hospital in the Byzantine Empire, Baltimore 1991, 50: "Christianity created the hospitals of the Byzantine Empire".

12 Por. W. Szumowski, Historia medycyny, Warszawa 1961, 101; A.H.M. Jones, The decline of the ancient world, London - New York 1975, 337: ,these were fields of social work which were almost entirely neglected by the government and by the old pagan upper class"; zob. też P. Bonfante, Istituzioni di diritto romano, Torino 1946, 65: „Le fondazioni sono un portato genuino del Cristianesimo, una emanazione della carità [...]". Również T. Sauvel (Les fondations. Leurs origines. Leur évolution, ,Revue du droit public et de la science politique en France et à l'étranger” [=RDS] 60:1954, s. 328) wyprowadza początki tych instytucji z inspiracji chrześcijańskiej: „leurs origines sont essentiellement chrétiennes”; podobnie J. Daniélou - H.I. Marrou, Historia Kościoła, t. 1: Od początków do roku 600, thum. M. Tarnowska, Warszawa 1984, 248: „Spotykamy się tu z zaczątkami instytucji, które [...] stały się głównym atrybutem każdego cywilizowanego państwa. Historyk cywilizacji winien podkreślić, że powstały one z inspiracji chrześcijańskiej, zrodziły się, 
Instytucje dobroczynne ${ }^{13}$ powstawały od pierwszych wieków chrześcijaństwa. Początkowo pochodziły głównie z majątku kościelnego, z czasem w ich tworzenie zaczęli się angażować ludzie świeccy oraz rodziny cesarskie ${ }^{14}$. Rozwojowi działalności dobroczynnej towarzyszyło życzliwe nastawienie rzymskiego ustawodawcy: stworzone zostały dogodne warunki w sferze prawnej. Proces prawnego wyodrębniania się instytucji z majątku kościelnego rozpocząl się w 2. poł. V wieku, kiedy to pojawiły się one w konstytucjach cesarskich obok ecclesiae, a więc jako podmioty odrębne. Proces ten został zakończony w prawie justyniańskim, w którym instytucje dobroczynne jawią się już jako uczestnicy obrotu prawnego, jako właściciele majątku ${ }^{15}$, wszelkie zaś decyzje zwią-

wzrosły i przez długie jeszcze wieki miały żyć pod skrzydłami Kościoła”. A. Jonecko ujmuje zasługi religii chrześcijańskiej $w$ tym okresie dla medycyny w trzy punkty: 1) zmiana nastawienia do chorych i potrzebujących pomocy, 2) przechowanie i przekazanie starożytnej wiedzy medycznej, 3) usprawnienie organizacji ochrony zdrowia; podkreśla również, że ,niedostatek wiedzy medycznej” Rzymianie nadrabiali „zorganizowanym działaniem humanistycznym” (Bazyli Wielki z Cezarei Kapadockiej i jego działalność w dziedzinie szpitalnictwa i opieki społecznej, ,Zdrowie Publiczne" 93:1982, nr 12, s. 595).

${ }^{13}$ Pojawieniu się instytucji dobroczynnych towarzyszyło tworzenie dla nich specjalnych nazw. Na podstawie tekstów kompilacji justyniańskiej można wnioskować o istnieniu następujących instytucji: 1. brephotrophium - dom dla porzuconych dzieci; 2. gerontocomium - dom dla osób starszych; 3. nosocomium - szpital; orphanotrophium - dom dla sierot; 4. ptochotrophium, ptochium - dom dla ubogich; 5. xenodochium, xenon - dom dla pielgrzymów.

W konstytucjach justyniańskich nie ma sformułowanych definicji poszczególnych rodzajów tych domów. Znajdują się one natomiast w streszczeniu Nowel Justyniana, dokonanym w VI wieku przez Julianusa Patriciusa, por. Const. VII, cap. XXXII, ad fin., ed. Haenel, 1873, s. 32; cyt. za P.W. Duff, Personality in roman private law, Cambridge 1938, 178: xenodochium: „locus venerabilis in quo peregrini suscipiuntur”; ptochotrophium: „in quo pauperes et infirmi homines pascuntur”; nosocomium: ,in quo aegroti homines curantur”; orphanotrophium: „in quo parentibus orbati pueri pascuntur"; gerontocomium: ,in quo pauperes et propter senectutem solam infirmi homines curantur"; brephotrophium: „in quo infantes aluntur”.

W Cesarstwie nie nastąpiło jeszcze ścisłe rozdzielenie funkcji poszczególnych domów. Podzial ich kompetencji traktować należy jako pewną regułę, praktykę, nie zawsze jednak zachowywaną. W żadnej konstytucji cesarskiej nie ma pełnego wykazu instytucji dobroczynnych. W literaturze zwraca się uwagę na brak wzmianek o dwóch zwłaszcza instytucjach, a mianowicie leprozoriach i domach dla niewidomych, choć wiadomo, że takie domy wtedy istniały; zob. na ten temat $\mathrm{F}$. Fabbrini, La personnalità giuridica degli enti di assistenza (detti 'piae causae') in diritto romano, „Apollinaris” 63 (1990) 60 oraz A. Philipsborn, Les établissements charitables et les théories de la personnalité juridique dans le droit romain, „Revue Internationale des Droits de l'Antiquite” [=RIDA] 3 (1951) 146n.

${ }^{14} \mathrm{Na}$ ten temat por. S. Longosz, Ksenodochium - hospicjum wczesnochrześcijańskie, VoxP 16 (1996) t. 30-31, 289-321. Justynian sam podkreślał hojność, jaką wykazywał zarówno on, jak i jego małżonka w stosunku do kościołów, klasztorów i instytucji dobroczynnych: „Quia igitur multa scimus tam nosmet quam serenissimam Augustam coniugem nostram variis personis iam donasse et vendidisse et per alios titulos adsignasse, et maxime sacrosanctis ecclesiis et xenonibus et ptochotrophiis et episcopis et monachis et aliis innumerabilibus personis [...]" (C. 7, 37, 3, 3).

15 Por. C. 1, 2, 19; C. 1, 2, 22; C.1, 2, 23, 4; Nov. 7, 5; Nov. 7, 6; Nov. 120, 7, 1; Nov. 120, 8; Nov. 131, 5. 
zane $\mathrm{z}$ zarządzaniem taką instytucją pozostawały pod kontrolą miejscowego biskupa $^{16}$.

Należy zauważyć, że zinstytucjonalizowana działalność charytatywna rozpoczęła się wcześniej na Wschodzie, i tam też powstała większa ilość zakładów dobroczynnych niż w Cesarstwie Zachodnim ${ }^{17}$. Przekazy dotyczące instytucji powstałych na Wschodzie są bardzo liczne ${ }^{18}$, potwierdzają stopniowe uniezależnianie się tych instytucji od majątku kościelnego. Zdecydowany krok w kierunku usamodzielniania się zakładów dokonał się na Wschodzie; zachodnia część Cesarstwa pozostawała niejako na uboczu tych przekształceń. Większość przekazów o istnieniu zakładów dobroczynnych na Zachodzie pochodzi dopiero $z$ wieków VII-IX ${ }^{19}$. Tym cenniejsze wydają się więc informacje o funkcjonowaniu takich domów, zawarte w Listach Grzegorza Wielkiego. Przedmiotem artykułu jest analiza statusu prawnego instytucji dobroczynnych na Zachodzie, wyłaniającego się z opisów zawartych w jego Listach. Warto wykazać w szczególności, czy ich stanowisko prawne podobne było do samodzielnych instytucji na Wschodzie i czy potwierdzają one wysuwaną przez wielu

${ }^{16}$ Por. C. 1, 3, 45. P.W. Duff (dz. cyt., s. 183) uważa, że w Cesarstwie mogły istnieć także instytucje, które nie podlegały opiece biskupa, wydaje się jednak, iż tekst powołanej ustawy nie pozwala na utrzymanie takiego poglądu; tak m.in. A. Philipsborn (dz. cyt., s. 143) oraz S. Wróblewski (Zarys wykładu prawa rzymskiego, Kraków 1916, 317): „poza Kościołem i jego opieką fundacje istnieć nie mogą"; zob. również P. Voci, Diritto ereditario romano, I, Milano 1954, 428; E. Stein, Histoire du Bas-Empire, II, Paris 1949, 398n; J.M. Casoria, De personalitate juridica 'piarum causarum' in evolutione juris romanorum usque ad divi Justiniani compilationem, Melphicti 1937, 76n. Wydaje się, że również Listy Grzegorza Wielkiego potwierdzają opinię, iz wszystkie instytucje dobroczynne podlegały biskupowi.

W wiekach IV-VI, w czasie naznaczonym wieloma wojnami, biskupi na Zachodzie mieli do wypełnienia szczególnie ważną rolę. Autorytet biskupów stanowił ważny element organizowania obrony miast, niesienia pomocy tym, którzy ucierpieli wskutek toczonych walk, oraz odbudowy zniszczonych miejsc. Biskup nierzadko zajmował się również mediacją z przywódcami wojsk nieprzyjacielskich, zob. S. Onory, Vescovi e città (sec. $I V-V I)$, ,Rivista di storia del diritto italiano" 4 (1931) 555-600. O roli biskupa w nauczaniu Grzegorza Wielkiego por. G.R. Evans, The thought of Gregory the Great, Cambridge 1986, 123-129.

17 Podkreśla się, że przyczyna takiego zjawiska mogła leżeć w świadczeniu pomocy w domach, co miałoby opóźnić powstawanie publicznych instytucji dobroczynnych. Fakt ten mógł być również spowodowany tym, że biskupi na Zachodzie posiadali skromniejsze zaplecze ekonomiczne, a co za tym idzie ograniczone możliwości zakładania domów dla potrzebujących, por. Imbert, dz. cyt., s. 1617; J. Gaudemet, Les fondations en Occident au Bas-Empire, RIDA 2 (1955) 275-286.

18 Tytułem przykładu podać można słynną „Bazyliadę” w Cezarei Kapadockiej, czy ksenodochium św. Samsona w Konstantynopolu; na ten temat por. J. Naumowicz, Instytucje charytatywne św. Bazylego. „Bazyliada”, VoxP 16 (1996) t. 30-31, 128-138; F. Bracha, Św. Bazyli twórca zakładów dobroczynnych, „Caritas” 5 (1949) nr 16, 5-9; G. Dagron, Naissance d'une capitale. Constantinople et ses institutions de 330 à 451, Paris 1974, 513; S. Longosz, Ksenodochium hospicjum wczesnochrześcijańskie, art. cyt. s. 289-307.

19 Por. W. Schönfeld, Die Ksenodochien in Italien und Frankreich im frühen Mittelalter, „Zeitschrift der Savigny-Stiftung für Rechtsgeschichte. Kanonistische Abteilung” 12 (1922) 1-54; S. Longosz, jw. s. 308-321. 
autorów tezę o podmiotowości prawnej takich instytucji w prawie justyniań$\operatorname{skim}^{20}$. Interesującą kwestią będzie również zbadanie, czy i w jakim zakresie postanowienia konstytucji cesarskich dotyczące zakładów dobroczynnych znalazły swoje odbicie w zarządzeniach wydawanych przez tego papieża. Należy również zaznaczyć, że analiza nie obejmuje wszelkich przejawów działalności dobroczynnej Grzegorza Wielkiego, a jedynie te sytuacje, kiedy skupia się ona na prowadzeniu zakładów. Kwestie te były poruszane w kilkunastu zaledwie listach, mimo to przynoszą wiele cennych informacji o statusie prawnym instytucji dobroczynnych.

\section{GRZEGORZ WIELKI O INSTYTUCJACH DOBROCZYNNYCH}

Grzegorz Wielki został wybrany na stolicę Piotrową w 590 roku $^{21}$. Był to okres na Zachodzie bardzo niespokojny: częste najazdy ludów barbarzyńskich oraz epidemia dżumy dziesiątkowała ludność. Tym bardziej więc konieczna wydawała się dobrze zorganizowana pomoc ubogim i chorym. Papież niekiedy osobiście nadzorował prowadzenie akcji dobroczynnej, gromadził i rozdysponowywał środki, apelował o zmniejszanie ciężarów nakładanych na ludność. Wszystko co daruje się ubogiemu - pisal - jest właściwie pożyczką, którą potem z zyskiem się odbiera ${ }^{22}$. Zebrane środki były przez niego natychmiast wyda-

${ }^{20}$ O stanowisku prawnym zakładów dobroczynnych w prawie rzymskim por. H. R. Hagemann, Die rechtliche Stellung der christlichen Wohltätigkeitsanstalten in der östlichen Reichshälfte, RIDA 3 (1956) 265-283; tenże, Die Stellung der Piae Causae nach justinianischem Rechte, Basel 1953; B. Eliachevitch, La personnalité juridique en droit privé romain, Paris 1942, 327-349; R. Saleilles, De la personnalité juridique, Paris 1922, 140nn; J.L. Murga, Testamentos y donaciones 'in bonum animae' y la llamada teoria de la personalidad juridica, , Rivista italiana per le scienze giuridiche" 95 (1968) 1-46.

${ }^{21}$ Koleje życia Grzegorz Wielkiego opisuje m.in. J. Czuj, Papież Grzegorz Wielki, Warszawa 1948; M. Banniard, Geneza kultury europejskiej V-VIII wieku, tłum. A. Kuryś, Warszawa 1995, 133-137; Histoire de l'Eglise, ed. A. Fliche et V. Martin, t. 5, Paris 1947, 18-25.

${ }^{22}$ Por. Epistula X 8 (cytaty i układ listów Grzegorza Wielkiego według CCL 140 i 140A, tłumaczenie na język polski: Grzegorz Wielki, Listy, thum. J. Czuj, I-IV, Warszawa 1954-55). O działalności dobroczynnej prowadzonej przez Grzegorza Wielkiego por. np. J. Czuj, Caritas u papieża Grzegorza Wielkiego, „Caritas” 3 (1947) nr 21, 150-154; La carità, dz. cyt., s. 104-108; M. Rouche, Grégoire le Grand face à la situation économique de son temps, w: Grégoire le Grand, ed. J. Fontaine - R. Gillet - S. Pellistrandi, Paris 1986, 48-53; F. Tarducci, Storia di S. Gregorio Magno e del suo tempo, Roma 1909, 131-138. W Listach znaleźć można szereg przykładów prowadzonej przez papieża działalności charytatywnej, i to nie tylko instytucjonalnej na szeroką skalę, ale również świadczonej pomocy pojedynczym osobom, o których ubóstwie czy chorobie Grzegorz miał wiadomość, zob. np. Ep. I 23 (nakaz wypłacania zasiłków „służebnicom Bożym w mieście Nola"); Ep. I 58 (wypłata rocznego zasiłku dla Palatyny cierpiącej niedostatek); Ep. III 21 (darowanie długu sierotom); Ep. VI 4 (przekazanie jedzenia dla głodujących); Ep. VI 10 (polecenie zakupu ubrania dla ubogich). Warte podkreślenia jest również zaangażowanie papieża w akcję wykupu jeńców (np. Ep. III 16; VI 32; VII 13; VII 35; IX 52). 
wane na najpilniejsze potrzeby ${ }^{23}$. Działalność taka pozostawała wypełnieniem nauczania Grzegorza o doskonałej formie życia, jaką stanowi połączenie życia aktywnego i kontemplacji ${ }^{24}$.

Pomimo upadku Cesarstwa Zachodniego i utraty ziem na Zachodzie odzyskanych częściowo za czasów Justyniana, nie zmieniło się poczucie, że panowanie wciąż należy do Cesarstwa Rzymskiego, mimo podbojów dokonanych na Zachodzie przez plemiona germańskie. Cesarz Maurycjusz (582-602) utworzył z ziem zachodnich, które pozostały jeszcze pod panowaniem Cesarstwa, dwa egzarchaty: Rawenny i Kartaginy ${ }^{25}$. Dowodem na poczucie przynależności do Cesarstwa Rzymskiego są również Listy Grzegorza Wielkiego, w których powołuje się on niejednokrotnie na konstytucje cesarskie dla wyjaśnienia wątpliwych kwestii przedstawianych mu do rozstrzygnięcia ${ }^{26}$. Prawo cesarskie i wewnętrzne prawo Kościoła były podstawą, na której opieral zarządzanie majątkiem kościelnym.

W Listach Grzegorza występują trzy rodzaje instytucji dobroczynnych: ksenodochia, ptochia oraz gerontokomia. Zdecydowanie najczęściej pisze Grzegorz Wielki o różnych sprawach związanych z działalnością ksenodochium $^{27}$. Wydaje się więc, że takich instytucji było najwięcej, i spośród różnych rodzajów domów dla ubogich chyba te były najbardziej rozpowszechnione. Budowane często wzdłuż uczęszczanych tras pielgrzymkowych, pełniły niekiedy również rolę szpitali ${ }^{28}$. Ksenodochia pełniły też prawdopodobnie funkcje najbardziej ogólne ${ }^{29}$. Na czele instytucji dobroczynnej stał zarządca. Grzegorz Wielki zalecał, aby był nim zakonnik ${ }^{30}$, choć trzeba zaznaczyć, że według prawa

${ }^{23}$ Celnie ujmuje to M. Rouche (Grégoire le Grand, dz. cyt., s. 52) pisząc: ,avec lui, l'argent circule".

${ }^{24}$ O nauczaniu papieża por. P. Gwiazda, ,Bonus ordo vivendi”- zycie doskonate w doktrynie św. Grzegorza Wielkiego, w: Duchowość przetomu wieków, red. S. Urbański - M. Szymula, Warszawa 2000, 193-211; autor ten zauważa: ,,[...] to, co św. Grzegorz nazywa życiem aktywnym, to uczynki miłosierdzia względem ciała i duszy [...]. Jest więc jednoznacznie, w myśli Grzegorza Wielkiego, życie aktywne - życiem miłości bliźniego" (tamże, s. 208). Na ten temat zob. także S. Sojka, Kaptan - pasterz wedtug świętego Grzegorza Wielkiego, w: Najważniejsza jest miłość. Księga Pamiq̨tkowa ku czci Księdza Profesora Waleriana Stomki, red. M. Chmielewski, Lublin 1999, 233 251 oraz C. Dagens, Saint Grégoire le Grand, Paris 1977, 145-153.

25 Por. G. Ostrogorski, Dzieje Bizancjum, tłum. pod red. H. Evert-Kappesowej, Warszawa 1967,81 i 89.

${ }^{26}$ Por. np. Epistulae IX 198 i XIII 50.

27 O genezie tego terminu por. S. Longosz, dz. cyt., s. $280 \mathrm{nn}$.

28 Taka funkcja xenonu wynika np. z C. 6, 4, 4, 2 i C. 7, 6, 1, 3; właściciel chorego niewolnika był zobowiązany odpowiednio zadbać o jego leczenie, co przejawiać się mogło m.in. w oddaniu go do xenonu. Należy więc przypuszczać, że instytucje te miały również na celu świadczenie pomocy medycznej.

${ }^{29}$ E. Wipszycka słusznie zauważa, że, zwłaszcza w mniejszych miastach lub na wsiach, nie było możliwości ani konieczności tworzenia kilku wyspecjalizowanych domów; osoby potrzebujące różnorakiej pomocy umieszczano w jednym domu (dz. cyt., s. 115). 
rzymskiego nie było takiego wymogu. Zgodnie $\mathrm{z}$ ustawodawstwem cesarskim prawo do wyznaczenia administratora przysługiwało zasadniczo fundatorowi ${ }^{31}$. W wypadku, gdy fundator tego nie uczynił, albo gdy wyznaczeni źle sprawowali urząd i zostali usunięci, albo wreszcie gdy instytucja dobroczynna była tworzona z majątku kościelnego, wybór zarządcy należał do biskupa. Zarządca według prawa powinien być osobą uczciwie wypełniającą swoje obowiązki, bogobojną, zachowującą pamięć o dniu, w którym jej uczynki zostaną osądzone przez $\mathrm{Boga}^{32}$. Sobór Chalcedoński (451 r.) podkreślił zasadę podległości biskupowi osób pracujących w instytucjach dobroczynnych. Jednocześnie $z$ brzmienia tego kanonu (8) wynika, że zarządca mógł być zarówno duchownym lub zakonnikiem, jak i osobą świecką ${ }^{33}$.

W jednym ze swych listów (I 9) Grzegorz Wielki rozstrzyga kwestię ważności testamentu sporządzonego przez administratora ksenodochium. Zarządca, jako zakonnik, nie mógł rozporządzać swoimi dobrami, które po wstąpieniu do klasztoru, właśnie klasztorowi przypadały na własność ${ }^{34}$. W tym jednak wypadku, z racji na bliżej nam nieznane okoliczności, papież nakazuje utrzymać testament w mocy ${ }^{35}$. Ważną kwestią było też zapewnienie realizacji rozporządzeń ostatniej woli pobożnych testatorów, nakazujących wybudowanie nowej instytucji dobroczynnej. Ustawodawstwo cesarskie stanowczo formułowało nakaz ścisłego wypełnienia rozporządzeń na cele dobroczynne ${ }^{36}$. Podob-

${ }^{30}$ Por. np. Epistula IV 24.

${ }^{31}$ Por. C. 1, 2, 15, 3; Nov. 131, 10, 2.

${ }^{32}$ Por. C. 1, 3, 45, 3: ,[...] qui magni dei timorem in mente habeant et terribilem magni aeternique iudicii diem, cuius respectu omnia eos intento in deum animo facere oportet". Justynian zachęcał zarządców, aby przekazywali swój majątek na rzecz instytucji, taką zaś darowiznę nazywał uczynioną ,,pro salute animae suae” (Nov. 123, 16, 2).

${ }^{33}$ Por. Concilium Chalcedonense can. 8, Mansi VII 375, lub Dokumenty Soborów Powszechnych, tekst grecki i polski, oprac. A. Baron - H. Pietras, Kraków 2001, 233. Kanon dotyczy pozycji osób stojących na czele zakładów dobroczynnych, klasztorów i świątyń pod wezwaniem męczenników. Ich obowiązkiem jest pozostawanie pod władzą miejscowego biskupa. W razie niesubordynacji podlegać mają przepisanym karom. Komentarz do tego kanonu daje G. Barone Adesi, Dal dibattito cristiano sulla destinazione dei beni economici alla configurazione in termini di persona delle venerabiles domus destinate piis causis, w: Atti dell'Accademia Romanistica Costantiniana IX, Napoli 1993, 255.

${ }^{34}$ Zasadę tę wyraża również Epistula IX 198.

35 Por. Epistula I 9, CCL 140, 11: „Testamentum vero Bacaudae quondam xenodochi in ea, qua conditum est, volumus firmitate persistere".

${ }^{36}$ Por. C. $1,2,14,1$; C. 1, 3, 45, 2 a i 6. Justynian wielokrotnie zapewniał, że jego zamiarem jest dokładne wykonanie zaleceń fundatora zakładu dobroczynnego. Nie ma powodu wątpić w tak sformułowane priorytety cesarza, zauważyć jednak trzeba pewną skłonność Justyniana do poddawania zarządzeń fundatora, jeśli nie ograniczeniom, to przynajmniej dokładnej kontroli; jak to ujmuje H.R. Hagemann (Die Stellung, dz. cyt., s. 51): „Justinian scheint bestrebt zu sein, dieses Sicheinmischen des Stifters in die Verwaltung seiner Stiftung einzudämmen und in unschädliche Bahnen zu lenken”; zob. też Miller, dz. cyt., s. 107n. O rozporządzeniach na cele dobroczynne w prawie justyniańskim por. T. Kunderewicz, Disposizioni testamentarie e donazioni a scopo di 
nie stanowczo wypowiadał się na ten temat Grzegorz Wielki, powołując się zresztą na konstytucje cesarskie. Działanie mające na celu zatrzymanie majątku, który powinien przypaść miejscom nazywanym „venerabiles”, określa cesarz jako ,sacrilegium et contra leges" ${ }^{37}$. W sprawie ostatniej woli niejakiego Izydora polecił nakłonić spadkobierców do jej zrealizowania, gdyż inaczej grozić im będą kary wskazane przez prawo. Wspomniany Izydor zobowiązał swoich spadkobierców do wybudowania ksenodochium. Równocześnie papież chronił w pewien sposób także dziedziców, przewidując sytuację, w której majątek pozostawiony przez zmarłego okazałby się zbyt mały na realizację jego ambitnych projektów. W takim wypadku dobra przypaść mają innej, już istniejącej, instytucji dobroczynnej - ksenodochium św. Teodora. Grzegorz argumentuje, że postanowienie takie nie sprzeciwia się woli testatora, gdyż przeznaczenie majątku jest zgodne $z$ zamiarem zmarłego ${ }^{38}$. Podobne rozstrzygnięcia znajdują się w ustawodawstwie cesarskim; dziedzice mogli uwolnić się od obowiązku wybudowania instytucji, jeżeli wykazali, że majątek spadkowy nie wystarcza na wykonanie takiej inwestycji. W takim przypadku dobra przypaść miały biskupowi, który powinien je przeznaczyć na cele wskazane przez testatora $^{39}$. Zarządzenia papieża wydają się więc być komplementarne w stosunku do zasad wskazanych przez Justyniana.

Instytucje dobroczynne uczestniczyły czynnie w obrocie prawnym. W liście IV 8 ksenodochium biskupa Tomasza jawi się jako dzierżawca nieruchomości. List ten, adresowany do biskupa Caralis Januariusza, rozstrzygał spór, jaki toczono w związku z tym gruntem. Zmarły mąż ,pobożnej niewiasty Teodozji” nakazał wybudowanie klasztoru właśnie na terenie tej posiadłości. Ponieważ Teodozja nie chciała wchodzić w spór z instytucją dobroczynną, prosiła o pozwolenie założenia klasztoru we własnym domu, na co zresztą papież wyraził zgodę $^{40}$. Na uwagę zasługuje sformułowanie „,xenodochium Thomae”. Określenie takie wskazuje zapewne na fakt, że zmarły biskup sprawował nad nim kontrolę, a prawdopodobnie był również jego założycielem. Nie wydaje się natomiast, że oznacza ono instytucję jako część majątku kościelnego, skoro w cytowanym liście podmiotem stosunku prawnego jest sama instytucja a nie Kościół biskupi.

beneficenza nel diritto giustinianeo, „Studia et Documenta Historiae et Iuris” (=SDHI) 47 (1981) 47-92.

37 Por. Epistula IX 90, CCL 140A, 644.

38 Por. Epistula IX 35, CCL 140A, 595: ,[...] voluntas defuncti salubriter sumat effectum, dum, etsi in loco alio, ipsi tamen rei quicquid a testatore deputatum est erogatur".

39 Por. Nov. 131, 12pr.: „Si autem heres quae ad pias causas relicta sunt non impleverit, dicens relictam sibi substantiam non sufficere ad ista, praecipimus omni Falcidia vacante quicquid invenitur in tali substantia proficere provisione sanctissimi episcopi ad causas quibus relictum est".

${ }^{40}$ Por. Epistula IV 8, CCL 140-224. Sprawa ta była jeszcze poruszana w Ep. IV 10. 
Sprawa rozpatrywana przez papieża w liście IX 63 ukazuje instytucję dobroczynną jako podmiot, na rzecz którego można dokonać zapisu ${ }^{41}$. Tak właśnie uczynił Bonifacjusz; wykonanie zapisu było możliwe dopiero po uporządkowaniu jego majątku, o co apelował Grzegorz w innym liście ${ }^{42}$. Papież zwraca się z prośbą do pisarza Azymarcha o udzielenie pomocy wdowie po Bonifacjuszu i zajęcie się „sprawą ubogich”, którym zostawił on część spadku. Takie sformułowanie wskazuje, że dobra pozostawiane instytucjom dobroczynnym były określane zamiennie jako dobra należące do ubogich, beneficjariuszy danego domu ${ }^{43}$. Było to zgodne $\mathrm{z}$ tendencją, którą zaobserwować można w konstytucjach cesarskich; stanowią one, że jeśli testator pozostawił majątek biednym, nie uściślając, o jaką grupę osób chodzi ${ }^{44}$, majątek przypadał ksenodochium znajdującemu się w rodzinnym mieście spadkodawcy, a zarządca tego domu miał obowiązek rozdysponować środki na rzecz ubogich znajdujących się pod jego opieką ${ }^{45}$.

Sporne kwestie związane $\mathrm{z}$ pozostawieniem legatu dla ksenodochium rozstrzygał papież również w liście IX 198. Syryka, ksieni jednego z klasztorów, po objęciu urzędu przełożonej sporządziła testament, w którym ustanowiła kilka legatów. Jednym z obdarowanych było ksenodochium. Zgodnie z prawem argumentuje Grzegorz - z chwilą wstąpienia do klasztoru majątek Syryki przypadł klasztorowi, nie mogła więc nim rozporządzać w drodze testamentu. Konsekwencją tego jest więc stwierdzenie, że instytucja posiada zapisany majątek niezgodnie z prawem. Papież polecił biskupowi Januariuszowi dopilnować oddania dóbr klasztorowi. Przedtem jednak powinien upewnić się, że jedynym tytułem, na który powołuje się instytucja dobroczynna, jest niezgodny z prawem legat; mogło się bowiem zdarzyć, że nabyła majątek w drodze umowy między stronami ${ }^{46}$. Rozstrzygnięcie sporu pozostawił $\mathrm{w}$ rękach biskupa lub

${ }^{41}$ Por. Epistula IX 63, CCL 140A, 619-620. Możliwość dokonania tego rodzaju przysporzeń na rzecz instytucji dobroczynnych zawarta jest m.in. w C. 1, 3, 45pr.: „Sancimus, si quis moriens piam dispositionem faciat vel institutionis modo vel per legatum vel per fideicommissum vel per mortis causa donationem vel per quemlibet alium legitimum modum [...]".

${ }^{42}$ Por. Epistula IX 131.

${ }^{43}$ Por. Epistula IX 63, CCL 140A, 620: ,[...] de pauperibus, quibus, sicut diximus, isdem Bonifatius hereditatis suae partem dereliquit [...]".

${ }^{44}$ Por. C. 1, 3, 48, 3: „[...] ubi indiscrete pauperes scripti sunt heredes”.

45 Justynian określił szczegółowo sposób dysponowania dobrami: zarządca powinien przeznaczyć dla biednych coroczne wpływy z majątku bądź za środki uzyskane ze sprzedaży rzeczy ruchomych nabyć nieruchomości, aby zapewnić biednym stały dochód. W sytuacji, kiedy w mieście znajduje się więcej instytucji dobroczynnych, biskup ma wyznaczyć najbiedniejszą z nich i ta otrzyma majątek. Gdyby, przeciwnie, wámieście nie było żadnych instytucji dobroczynnych, dobra należy przyznać miejscowemu biskupowi, záobowiązkiem przeznaczenia ich na ubogich z danego miasta (C. 1, 3, 48, 5-6). Komentarz do tej konstytucji u Hagemanna, Die Stellung, s. 66-70; Kunderewicz, Disposizioni, s. 86-87; Eliachevitcha, dz. cyt., s. 345-346.

${ }^{46}$ Por. Epistula IX 198, CCL 140A, 756: „Et ideo quia ex dimissis illicite rebus xenodochium possessionem asserit indebite detinere, his vos hortamur affatibus ut, quia et monasterium et 
wybranych przez zainteresowane podmioty arbitrów. Decyzja arbitrów miała być ostatecznym rozwiązaniem sporu, w którym uczestniczyły „,venerabilia loca" 47 .

W kilku innych listach papież Grzegorz I wydawał decyzje dotyczące rozwiązania sporów o nieruchomości. W liście IX 67 odniósł się do kontrowersji wokół przynależności majątków Faianum, Nasonianum i Libinianum znajdujących się w prowincji sycylijskiej. Prawo do tych terenów rościł sobie klasztor zwany Lucuscanum oraz ksenodochium nazywane domem Waleriusza. Spór ciągnął się, wedle słów papieża, bardzo długo, ale udało się wreszcie zawrzeć porozumienie między opatem Domicjuszem i zarządcą Antoniuszem. Grzegorz zatwierdził zawartą ugodę i zakazał jej naruszania w przyszłości ${ }^{48}$.

Problemy w zarządzaniu powodowała też niekiedy wspólnota majątku ${ }^{49}$, którego właścicielami byli klasztor świętych Erazma, Maksyma i Juliany oraz ksenodochium św. Teodora. Fuskus, opat klasztoru, prosił o dokonanie podziału, na co zgadzał się Grzegorz Wielki i nakazał Romanowi, obrońcy Sycylii, udzielenie wszelkiej pomocy w tej sprawie. Jednocześnie Fuskus utrzymywał, że instytucja dobroczynna odziedziczyła spadek, z którego powinna klasztorowi wydać pozostawiony mu zapis. Papież nakazał sprawdzenie podanych okoliczności i w razie potwierdzenia słów opata dopilnowanie wydania zapisu ${ }^{50}$.

Do kwestii zarządzania i kontroli nad instytucjami dobroczynnymi powracał Grzegorz jeszcze m.in. w liście IV 24. List ten stanowi upomnienie skierowane do biskupa miasta Caralis Januariusza z powodu zaniedbań w opiece nad znajdującymi się na podległym mu terenie zakładami ${ }^{51}$. Papież przypomina o obowiązku opieki nad takimi domami ze strony biskupów. Zarządcy, których powołują, powinni być godni sprawowania tego zaszczytnego urzę-

xenodochium ipsum in vestra civitate est positum, omni cura ac providere studio debeatis, quatenus, si possessio ipsa ex nullo praecedenti contractu sed ex memoratae Siricae legato descendit, antedicto monasterio, postposito strepitu vel excusatione, reddatur".

${ }^{47}$ Podobnie ogólne określenia na oznaczenie instytucji dobroczynnych, a zarazem kościołów i klasztorów występują w konstytucjach cesarskich, np. „,pia domus”, ,venerabilis locus”, ,pius locus", ,venerabilis domus".

${ }^{48}$ List IX 67 (CCL 140A, 622-623) adresowany jest do opata Domicjusza, stojącego na czele uczestniczącego w sporze klasztoru. List o takiej samej treści skierował papież również do zarządcy Antoniusza, kierującego instytucją dobroczynną, która zawarła porozumienie w sprawie spornych terenów (Ep. IX 83, CCL 140A, 637-638). Analizę tych listów przeprowadza M.B. Dunn, The style of the letters of St. Gregory the Great, Washington 1931, 37-40.

${ }^{49}$ Współwłasność można było w prawie rzymskim znieść przez porozumienie współwłaścicieli; wábraku takiego porozumienia każdemu z uczestników przysługiwało powództwo działowe, por. K. Kolańczyk, Prawo rzymskie, Warszawa 1997, 291.

${ }^{50}$ Por. Epistula IX 171, CCL 140A, 729.

51 Por. Epistula IV 24, 140A, 242: „Oportebat quidem fraternitatem tuam ita de rebus piis esse sollicitam, ut nihil ad explendas eas nostrae admonitionis penitus indigeret. Tamen quia quaedam ad nos pervenerunt quae sunt corrigenda capitula, nihil est incongruum si nostrae quoque vobis pagina auctoritatis accedat". 
$\mathrm{du}^{52}$. Zauważyć należy, że również w ustawodawstwie cesarskim jasno ustalona była zasada nadzoru biskupa nad zarządzaniem instytucją. Justynian zastrzegł dla wszystkich instytucji nadzór miejscowego biskupa, i to nawet wówczas, gdy fundator expressis verbis wyraził wolę wyłączenia go z zarządzania domem. Takie zarządzenie fundatora ma być uznane za niedokona$\mathrm{ne}^{53}$. Do biskupa należała ocena, czy czynności administratora przynoszą korzyść instytucji. W razie negatywnej opinii biskup powinien w pierwszej kolejności upomnieć zarządcę, a gdyby nie przyniosło to skutku przysługiwało mu uprawnienie do jego usunięcia ${ }^{54}$. Zarządcy mieli obowiązek składania dokładnych rachunków $\mathrm{z}$ administrowania instytucją przed biskupem ${ }^{55}$. Zaniedbanie tego właśnie obowiązku było główną przyczyną wystosowania upomnienia do Januariusza. Papież powrócił do tej sprawy w liście do Witalisa, obrońcy Sardynii. Tłumaczył, że nie zamierza więcej karcić Januariusza ze względu na jego wiek i chorobę, chciał jednak koniecznie uporządkować sprawy związane z instytucjami dobroczynnymi na Sardynii. Zlecił Witalisowi, wraz z przybranymi pomocnikami, wykonanie tego zadania ${ }^{56}$.

Grzegorz Wielki prowadził również korespondencję z Brunhildą, królową Franków. Wybudowała ona m.in. kościół św. Marcina, klasztor i ksenodochium $^{57}$. Papież, na jej prośbę, udzielił im specjalnych przywilejów. Przywileje dla ksenodochium wymienił w liście do jego zarządcy, Senatora ${ }^{58}$. Potwierdził, że rzeczy należące do instytucji nie mogą być przez nikogo zabrane, nawet na inne zbożne cele ${ }^{59}$. Grzegorz niekonsekwentnie wyraża przynależność majątku

${ }^{52}$ Por. tamże: „Atque tales in eis qui praesint ordinentur, qui vita, moribus atque industria inveniantur esse dignissimi [...]". Stanowisko zarządcy było odpowiednim miejscem na wykazanie się swoimi umiejętnościami. Papież poleca zbadać jak wywiązywał się z powierzonych mu obowiązków Krescens, kandydat na biskupa, wcześniej zarządca ksenodochium. Trzeba zobaczyć argumentuje Grzegorz - jak postępował w rzeczach małych, żeby przekonać się, jaki będzie w rzeczach wielkich (Ep. XIII 12).

53 Por. C. 1, 3, 45pr.

${ }^{54}$ Por. C. 1, 3, 45, 3: ,[...] eorum administrationem inspiciant et, si recte se habet, collaudent, si quid praetermittitur, emendent, si vero pessime geritur, illos expellant aliosque instituant [...]"; zob. też. Nov. 131, 10, 2.

55 Obowiązek składania rachunków przed biskupem wynikał z Nov. 123, 23. Na podstawie przedłożonych sprawozdań biskup miał ustalić, czy nie powstały straty, a jeżeli tak, zarządca musiał je wyrównać. Jeżeli zarządca zmarł przed dokonaniem rozliczenia, obowiązek ten przechodził na jego spadkobierców.

56 Por. Epistula XIV 2, CCL 140A, 1066-1069

57 Por. Epistula XIII 5, CCL 140A, 997-1000.

58 Por. Epistula XIII 9. List ten, jak i dwa inne przyznające specjalne przywileje na prośbę Brunhildy, wywołały wiele kontrowersji co do ich autentyczności; por. Dunn, dz. cyt., s. 42-50.

59 Użyte przez papieża wyrażenie „donata sunt... xenodochio” wskazuje wyraźnie na instytucję dobroczynną jako podmiot, na rzecz którego dokonywana jest darowizna. Uprawnienie do przyjmowania darowizn zostało przyznane zakładom dobroczynnym przez cesarza Zenona (C. 1, $2,15,1)$. Na biskupa został nałożony obowiązek egzekwowania należności przyrzeczonych przez darczyńcę (C. 1, 2, 15,2). Darczyńca, który nie dotrzymał obietnic, określony jest przez Justyniana 
instytucji, raz traktując ją jako właściciela, a za chwilę uznając za właściciela zarządcę. Sytuacja taka, występująca często także w ustawodawstwie cesarskim $^{60}$, wynikała $\mathrm{z}$ niewykształconej jeszcze teorii osobowości prawnej w tamtym okresie ${ }^{61}$ i stanowi silny argument dla przeciwników uznania zakładów dobroczynnych za osoby prawne w prawie rzymskim.

Papież ustalił także tryb wyboru zarządców oraz obostrzony tryb usuwania ich z urzędu. Administrator mógł być pozbawiony zarządu tylko w wyniku dokonania poważnego występku ${ }^{62}$. Grzegorz zdecydowanie zakazał przyjmowania korzyści majątkowych w sprawach dotyczących zakładu. Zabronił również zarządcom ubiegania się o stanowisko biskupa.

Dużo rzadziej niż ksenodochia ${ }^{63}$ przewija się w Listach inny rodzaj instytucji dobroczynnej, a mianowicie ptochium. W jednym z nich, adresowanym do subdiakona Piotra, zarządcy majątku na Sycylii ${ }^{64}$, papież polecił mu pokryć wydatki, jakie poniósł na rzecz tej instytucji z dochodów kościelnych ${ }^{65}$. Natomiast w liście IX 124 wspomina o konieczności kupienia niewolników dla takiego ptochium ${ }^{66}$. W jednym tylko liście zaświadcza Grzegorz o funkcjonowaniu również domów dla osób w podeszłym wieku (gerontocomia). Dowiedziawszy się o trudnej sytuacji finansowej takiego przytułku - założonego przez Izaura - posyła koce, łóżka i pieniądze ${ }^{67}$.

jako „impius”; grozić mu mają kary nie tylko przewidziane w prawie, ale i boskie - ,,caelestes” (C. 8, $53,35,5$ d). Kwestie dotyczące darowizny na cele dobroczynne regulowane są jeszcze w C. 1, 2, 19; C. 8, 53, 34, 1a; Nov. 120, 9pr, por. G.G. Archi, La donazione, Milano 1960, 85nn; B. Biondi, Successione testamentaria e donazioni, Milano 1955, 110nn; E. Bussi, La donazione nel suo svolgimento storico, w: Cristianesimo e diritto romano, Milano 1935, 171-294; J.L. Murga, Los negocios 'pietatis causa' en las constituciones imperiales postclásicas, „Anuario de Historia del Derecho Español" [=AHDE] 37 (1967) 276nn.

${ }^{60}$ Tak np. w Nov. 120, 7, 1: Justynian zwraca się zarówno do instytucji, jak i do zarządców jako właścicieli, podobnie w Nov.120,8. Z drugiej jednak strony, zarówno w ustawodawstwie cesarskim, jak i w Listach Grzegorza Wielkiego obserwować można silną tendencję do rozgraniczania majątku zarządcy i kierowanego przez niego zakładu.

${ }^{61}$ Por. W. Litewski, Jurysprudencja rzymska, Kraków 2000, 110: „Charakterystyczna dla jurysprudencji rzymskiej niechęć do abstrakcji pozostawała w związku z panującym ukierunkowaniem na kazuistykę i orientację praktyczną [...]. Wyraźna była niechęć do ustalania pojęć i ich teorii prawnodogmatycznych [...]. Nie sformułowano również pojęć podmiotu prawa, osoby prawnej i jej rodzajów [...]. Brak tu było nawet terminów technicznych”, zob. też Eliachevitch, dz. cyt., 347; R. Longchamps de Bérier, Studia nad istota osoby prawniczej, Lwów 1911; H. Insadowski, Osoba prawna. Studium prawno-kanoniczne, Lublin 1927, 73; Kolańczyk, dz. cyt., s. 205.

${ }^{62}$ Por. Epistula XIII 9, CCL 140A, 1005: ,[...] nisi causa specialiter criminis exigente”.

${ }^{63}$ Poza przytoczonymi wyżej listami ksenodochia wzmiankowane są jeszcze w Ep. IX, 219 i XIII, 26.

${ }^{64} \mathrm{O}$ formowaniu się majątku kościelnego na Sycylii w tamtym okresie por. Putrino, dz. cyt., s. $1-14$.

${ }^{65}$ Por, Epistula II 38, CCL 140A, 122-125.

${ }^{66}$ Por. Epistula IX 124, CCL 140A, 675.

67 Por. Epistula XI 2, CCL 140A, 860. 
W jednym z listów określa Grzegorz zakłady dobroczynne terminem ,,piae causae" $" 68$. Termin ten wzbudza wciąż kontrowersje ${ }^{69}$, choć bywa szeroko stosowany na określenie instytucji i jest uznawany za termin źródłowy. Należy podkreślić, że określenie to występuje jedynie w kilku konstytucjach wydanych przez Justyniana ${ }^{70}$ i powoduje wątpliwości czy rzeczywiście bywa użyte na określenie podmiotu prawa - instytucji dobroczynnej. Wydaje się jednak, że Grzegorz Wielki posłużył się tym terminem w takim właśnie znaczeniu. W innym jednak miejscu określenie „causa pia”, użyte przez papieża, oznacza jedynie cel, motyw działania, a nie podmiot prawa ${ }^{71}$. To zamieszanie terminologiczne potwierdza wątpliwości dotyczące rzeczywistego znaczenia tego wyrażenia w prawie rzymskim.

Poczyniona wyżej analiza pozwala na sformułowanie kilku wniosków. Przede wszystkim należy stwierdzić, że Listy Grzegorza Wielkiego dostarczają aż nadto dowodów na istnienie i prowadzenie działalności przez instytucje dobroczynne w tamtym okresie. Wydaje się, że instytucje te były liczne, zwłaszcza ksenodochia. Były one uczestnikami obrotu prawnego; pojawiają się w Listach jako dzierżawcy nieruchomości, podmioty, na rzecz których można dokonać zapisu oraz mogące dziedziczyć, są nazywani właścicielami nieruchomości. Wydaje się, że okoliczności te potwierdzają opinię, zgodnie z którą instytucje te były traktowane jako „subiectum iuris”. Oczywiście, można również odnaleźć argumenty zaprzeczające podmiotowości zakładów, ale wątpliwości te wynikają z faktu, że w ówczesnej myśli prawnej brak było refleksji dogmatycznej nad tym zagadnieniem.

${ }^{68}$ Por. Epistula XIV, 2, CCL 140A, 1067: „Pro requirendis vero rebus ecclesiarum vel monasteriorum sive piarum causarum [...]".

${ }^{69}$ Por. S. Cugia, Il termine piae causae”, „Studi Fadda”, V, Napoli 1905, 227-264; po dokonaniu analizy określenia „causa pia” Cugia dochodzi do wniosku, iż „causa” nie może w żadnym wypadku oznaczać podmiotu prawa. Wyrażenie ,,super piis causis”, jego zdaniem, nie pozwala na przypisanie terminowi „piae causae” znaczenia adresata norm, podmiotu czynności prawnych. Analiza tekstów źródłowych zawierających słowa „,super” i „,causa” prowadzi autora do konkluzji, że zwrot „,super piis causis” należy tłumaczyć jako ,propter pias causas”, czyli jako określenie celu, motywu działania. Określenie ,pia causa” nie ma stałego znaczenia; jest to po prostu „causa iusta” rozporządzeń na cele dobroczynne. W związku z tym ,piae causae” nie mogą być uważane, w ścisłym znaczeniu tego słowa, za termin. Z konkluzjami Cugii polemizuje J.M. Casoria, dz. cyt., s. 55-68 oraz R. Saleilles, Les 'piae causae' dans le droit justinien, w: Mélanges Gerardin, Paris 1907, 524-525; zob. również Duff, dz. cyt., s. 203-205; Fabbrini, dz. cyt., s. 59.

${ }^{70}$ Por. np. w C. 1, 2, 19; C. 8, 53, 34, 1a; Nov. 131, 11, 3; Nov. 131, 13pr.

71 W liście XIII 9 (CCL 140A, 1004-1006) papież zabronił przeznaczania rzeczy należących do instytucji dobroczynnej na jakieś niby zbożne cele (aliis quasi piis causis). 
Grzegorz Wielki, wypełniając i uzupełniając w tym zakresie konstytucje cesarskie, akcentował konieczność dokładnego wypełniania rozporządzeń ostatniej woli testatorów, którzy swój majątek pozostawiali instytucjom dobroczynnym. Wydawał zarządzenia precyzujące sposoby wypełnienia tego rodzaju postanowień. Regulował także kwestie związane z zarządzaniem zakładem oraz nadzorem sprawowanym przez biskupa. Uprawnione wydaje się stwierdzenie, że w zarządzeniach papieża realizowane były postanowienia prawa rzymskiego. Grzegorz powoływał się nierzadko na konstytucje cesarskie, wydawał rozporządzenia uzupełniające i precyzujące postanowienia konstytucji. Celem tych działań było zapewnienie zakładom dobroczynnym sprawnego funkcjonowania.

\section{GLI ISTITUTI DI BENEFICENZA NELLE LETTERE DI S. GREGORIO MAGNO}

(Sommario)

Nel presente articolo viene esaminata la posizione giuridica degli istituti di beneficenza, specialmente la loro subbiettività giuridica. Questo problema è trattato principalmente sulla basa delle Lettere di s. Gregorio Magno. Le Lettere attestano l'esistenza di tali istituti; l'ordinamento amministrativo degli enti ha impostazione religiosa. L'amministrazione degli istituti è posta sotto il continuo e diretto controllo del vescovo. Alla creazione di tali istituti contribuiscono le liberalità di molti privati, favorite dalla legislazione imperiale.

Dalle fonti esaminate risulta che gli istituti di beneficenza erano considerati quali persone giuridiche, vuol dire come enti capaci di diritti e capaci di agire. 